\title{
CURRENT BIBLIOGRAPHY
}

Recently published works pertaining to sedimentary geology in the Maritime regions and environs are listed below. They have been extracted from Abstracts of North American Geology for March, April, May, July, August, 1967. The June is sue is not available.

\section{Areal Geology}

BAIRD, D. M. , 1966, Rocks and scenery of Terra Nova National Park: Geol. Surv. Can., Misc. Rept. 12, 52 p.

CHUTE, N. E. , 1966, Geology of the Norwood quadrangle, Norfolk and Suffolk Counties, Massachusetts: U.S. Geol. Surv., Bull. 1163-B, p. Bl-B78.

DONALDSON, J. A., 1966, Marion Lake map-area, Quebec-Newfoundland (23I/13) [with French abs.] : Geol. Surv. Can., Mem. 338, 85 p.

EKREN, E. B. and FRISCHKNECHT, F.C., 1967, Geological-geophysical investigations of bedrock in the Island Falls quadrangle, Aroostook and Penobscot Counties, Maine; U.S. Geol. Surv., Prof. Paper 527, 36 p.

GRISCOM, A., 1966, Geology of the Ripogenus Lake area, Maine (with Trip BF road log): in Guidebook for field trips in the Mount Katahdin region, Maine; New England Intercollegiate Geol. Conf., 58th Ann. Mtg. 1966, Augusta, Maine (Maine Geol. Surv.), p. 36-41.

KANE, M. F. ; BROMERY, R. W. ; PAVLIDES, L. ; and FRISHKNECHT, F. C. , 1966, Geophysical and geological reconnaissance of the Oakfield Hills area, Maine: in Mining geophysics V. 1, Case histories; Soc. Explor. Geophysicists, Tulsa, Okla., p. 94-104.

KEYSER, J. H., 1966, La géologie de Montréal (with English summ. ): in Internat. Conf. Soil Mechanics and Found. Eng., 6th Montreal, 1965, Proc., v. 3; Toronto, Ontario, Univ. Toronto Press, p. 114-133.

NEWMAN, R. B. and RANKIN, D. R. J., 1966, Bedrock geology of the Shin Pond region: in Guidebook for field trips in the Mount Katahdin region, Maine; New England Intercollegiate Geol. Conf., 58th Ann. Mtg. 1966, Augusta, Maine (Maine Geol. Surv. ), p. 8-17.

ROBERT, J-L., 1966, Geology of Mount Hog's Back area, Gaspé North County: Quebec Dept. Nat. Resources, Prelim. Rept. 540, 24 p.

SMITH, J. C., 1966, Geology of southwestern New Brunswick (with French abs. ): in Geology of parts of Atlantic Provinces; Geol. Assoc. Can. and Mineralog. Assoc. Can., Guidebook, Halifax, Nova Scotia (Nova Scotia Dept. Mines), p. 1-12.

SRIRAMADAS, A., 1966, Geology of the Manchester quadrangle, New Hampshire: New Hampshire Dept. Resources and Econ. Devel., Bull. 2, $78 \mathrm{p}$.

UCHUPI, E., 1966, Map showing relation of land and submarine topography, DeSoto Canyon to Great Bahama Bank: U. S. Geol. Surv., Misc. Geol. Inv. Map I-475.

Economic Geology

BOYLE, R. W. and JAMBOR, J. L., 1966, Mineralogy, geochemistry, and origin of the Magnet Cove barite-sulphide deposit, Walton, N. S. : Cdn. Mining and Metall. Bull., v. 59, no. 654 , p. $1209-1228$.

DAVIES, J. L., 1966, Geology of Bathurst-Newcastle area, N. B. (with French abs. ): in Geology of parts of Atlantic Provinces; Geol. Assoc. Can. and Mineralog. Assoc. Can., Guidebook, Halifax, Nova Scotia (Nova Scotia Dept. Mines), p. 33-43.

, and SMITH, R. N., 1966, Geology of the Brunswick No. 6 and No. 12 sulphide deposits (with French abs.): in Geology of parts of Atlantic Provinces; Geol. Assoc. Can. and Mineralog. Assoc. Can., Guidebook, Halifax, Nova Scotia (Nova Scotia Dept. Mines), p. $45-57$.

MAGNET COVE BARIUM CORPORATION, 1966, Walton Mine, Nova Scotia (with French abs.): in Geology of parts of Atlantic Provinces; Geol. Assoc. Can. and Mineralog. Assoc. Can., Guidebook, Halifax, Nova Scotia (Nova Scotia Dept. Mines), p. 107-112.

McFARLANE, P. and GATES, W. J., 1966, Geology of the Heath Steele sulphide deposits (with French abs.): in Geology of parts of Atlantic Provinces; Geol. Assoc. Can. and Mineralog. Assoc. Can., Guidebook, Halifax, Nova Scotia (Nova Scotia Dept. Mines), p. 59-62.

MEYER, K. V.S., 1966, Geology of the Wedge Mine (with French abs.): in Geology of parts of Atlantic Provinces; Geol. Assoc. Can. and Mineralog. Assoc. Can., Guidebook, Halifax, Nova Scotia (Nova Scotia Dept. Mines), p. 63-65. 
ANDREWS, J. T., 1966, Pattern of coastal uplift and deglacierization,west Baffin Island, N. W. T. (with French abs.): Can. Dept. Mines and Tech. Surveys, Geog. Branch, Geog. Bull., v. 8, p. $174-193$.

BORNS, H. W. , Jr. and SWIFT, D. J. P., 1966, Surficial geology, north shore of Minas Basin, Nova Scotia (with French abs.): in Geology of parts of Atlantic Provinces, Geol. Assoc. Can, and Mineralog. Assoc. Can., Guidebook, Halifax, Nova Scotia (Nova Scotia Dept. Mines), p. 81-85.

CALDWELL, D. W., 1966, Pleistocene geology of Mt. Katahdin: Trip C in Guidebook for field trips in the Mount Katahdin region, Maine - New England Intercollegiate Geol. Conf., 58th Ann. Mtg., Augusta, Maine (Maine Geol. Surv.), p. 51-57.

DIONNE, J. -C., 1966, Formes de cryoturbation fossiles dans le sud-est du-Québec (with English abs. ): Cahiers Géographie Québec, v. 10, p. 89-100.

, 1966, Collines pyramidales des Appalaches de 1'est du-QuÉbec: Rev. Gëographie Montréal, v. 20, p. 102-104.

FALCONER, G., 1966, Preservation of vegetation and patterned ground under a thin ice body in northern Baffin Island, N. W. T. (with French abs.): Can. Dept. Mines and Tech. Surveys, Geog. Branch, Geog. Bull., v. 8, p. 194-200.

HARTSHORN, J.H., 1967, Geology of the Taunton quadrangle, Bristol and Plymouth Counties, Massachusetts; U.S. Geol. Surv., Bull. 1163-D, p. D1-D67.

HOLMES, G. W. , 1966, Early discoverers - (Pt. ) 25, Stephen Reed, M. D. , and the "celebrated" Richmond boulder train of Berkshire County, Massachusetts, U. S. A. : Jour. Glacialogy, v. 6, p. 431-437.

POQUET, J., 1966, Réflexions géomorphologiques relatives au Québec méridional: Cahiers Géographie Québec, v. 10, p. 107-113.

SCHWARTZ, M.L., (1967, The Bruun theory of sea-level rise as a cause of shore erosion; Jour. Geol., v. 75, p. 76-92.

STRAHLER, A. N., 1966, A geologist's view of Cape Cod: Natural History Press (for Amer. Mus. Nat. History), Garden City, N. Y., 115 p.

Igneous and Metamorphic Petrology

AUMENTO, F., 1966, Zeolite minerals, Nova Scotia (with French abs.): in Geology of parts of Atlantic Provinces; Geol. Assoc. Can. and Mineralog. Assoc., Guidebook, Halifax, Nova Scotia (Nova Scotia Dept. Mines), p. 71-78.

CHAKRABORTY, K. L. , 1966, Ferromagnesian silicate minerals in the metamorphosed ironformation of Wabush Lake and adjacent areas, Newfoundland and Quebec (with French, German, and Russian abs.): Geol. Surv. Can., Bull. 143, 34 p.

SWIFT, C. M. , Jr., 1966, Geology of the southeast portion of the Argyll quadrangle, New Hampshire: Concord, N. H., New Hampshire Dept. Resources and Econ. Devel., 19 p.

TAYLOR, F.C. and SCHILLER, E. A., 1966, Metamorphism of the Meguma Group of Nova Scotia: Cdn. Jour. Earth Sci., v. 3, p. 959-974.

\section{Stratigraphy}

BRÜCKNER, W. D., 1966, Stratigraphy and structure of west-central Newfoundland (with French abs. ): in Geology of parts of Atlantic Provinces; Geol. Assoc. Can. and Mineralog. Assoc. Can., Guidebook, Halifax, Nova Scotia (Nova Scotia Dept. Mines), p. 137-151.

GREINER, H. R. and POTTER, R. R., 1966, Silurian and Devonian stratigraphy, northern New Brunswick (with French abs.): in Geology of parts of Atlantic Provinces; Geol. Assoc. Can. and Mineralog. Assoc. Can., Guidebook, Halifax, Nova Scotia (Nova Scotia Dept. Mines), p. 19-29.

HALL, B. A., 1966, Stratigraphy and structure of the Chamberlain Lake region, Maine (with Trip BS road log): in Guidebook for field trips in the Mount Katahdin region, Maine; New England Intercollegiate Geol. Conf., 58th Ann. Mtg. 1966, Augusta, Maine (Maine Geol. Surv. ), p. $42-50$.

HATCH, N. L., Jr.; CHIDESTER, A. H.; OSBERG, P. H. ; and NOR TON, S. A., 1966, Redefinition of the Rowe Schist in northwestern Massachusetts; in Changes in Stratigraphic nomenclature by the U. S. Geological Survey 1965; U. S. Geol. Surv., Bull. 1244-A, p. A33-A35. 
KELLEY, D. G. , 1966, Stratigraphy of Cape Breton Island (with French abs. ): in Geology of parts of Atlantic Provinces; Geol. Assoc. Can. and Mineralog. Assoc. Can., Guidebook, Halifax, Nova Scotia (Nova Scotia Dept. Mines), p. 115-130.

MacNEILL, R. H. and HOPE-SIMPSON, D., 1966, Stratigraphy of Western Nova Scotia (with French abs. ): in Geology of parts of Atlantic Provinces; Geol. Assoc. Can. and Mineralog. Assoc. Can., Halifax, Nova Scotia (Nova Scotia Dept. Mines), p. 89-94.

NEWMAN, R. B., 1966, Road logs - The anticlinorium core, and the Silurian and Devonian rocks on its northwest flank; the southeast flank of the anticlinorium: in Guidebook for field trips in the Mount Katahdin region, Maine; New England Intercollegiate Geol. Conf., 58 th Ann. Mtg., Augusta, Maine (Maine Geol. Surv.), p. 18-27.

OSBORNE, F. F. and RIVA, J., 1966, Post-Levis beds of the Quebec Group at St. Appollinaire, Lotbiniere Co., P. Q. (with French abs.): Naturaliste Canadien, v. 2, p. 145-151. and BERRY, W. B. N. , 1966, Tremadoc rocks at Levis and Louzon (with French abs. ): Naturaliste Canadien, v. 2, p. 133-143.

PAVLIDES, L. , 1966, Meduxneheag Group and Spragueville Formation of Aroostook County, northeast Maine: in Changes in stratigraphic nomenclature by the U.S. Geological Survey, 1965; U. S. Geol. Surv., Bull. 1244-A, p. A52-A5 7.

SHEA, F.S., 1966, Lower Carboniferous stratigraphy of the Windsor-Horton district of Nova Scotia (with French abs.): in Geology of parts of Atlantic Provinces; Geol. Assoc. Can. and Mineralog. Assoc. Can., Guidebook, Halifax, Nova Scotia (Nova Scotia Dept. Mines), p. 99-106.

ZEN, E-an and RATCLIFFE, N. M. , 1966, A possible breccia in southwestern Massachusetts and adjoining areas, and its bearing on the existence of the Taconic Allochthon: in Geological Survey research 1966; U. S. Geol. Surv., Prof. Paper 550-D, p. D39-D46. , 1966, Stockbridge Formation, Wallomsac Formation, Egremont Phyllite, Everett Formation: in Changes in stratigraphic nomenclature by the U.S. Geological Survey 1965; U. S. Geol. Surv., Bull. 1244-A, p. A30-A32.

Structural Geology

BEMMELEN, R. W., van, 1966, The evolution of mega-undations - A mechanical model for large-scale geodynamic phenomena; in The world rift system - Internat. Upper Mantle Comm., Symposium, Ottawa, 1965; Geol. Surv. Can., Paper 66-14, p. 373-399.

BILLINGS, M. P. and RAHM, D. A., 1966, Geology of the Malden Tunnel, Massachusetts: Boston Soc. Civil Engineers Jour., v. 53, p. 116-141.

FYSON, W. K., 1966, Structures in the Lower Paleozoic Meguma Group, Nova Scotia: Geol. Soc. Amer., Bull. , v. 77, p. 931-943.

MacNEILL, R. H. and TAKE, W. F., 1966, Triassic basalt and structure, Nova Scotia (with French abs. ): in Geology of parts of Atlantic Provinces; Geol. Assoc. Can. and Mineralog. Assoc. Can., Guidebook, Halifax, Nova Scotia (Nova Scotia Dept. Mines), p. 67-70.

WIESNET, D. R. and CLARK, T. H. , 1966, The bedrock structure of Covey Hill and vicinity, northern New York and southern Quebec in Geological Survey research 1966; U. S. Geol. Surv., Prof. Paper 550-D, p. D35-D38.

Paleontology

BOUCOT, A. J. and YOCHELSON, E. L., 1966, Paleozoic Gastropoda from the Moose River synclinorium, northern Maine: U. S. Geol. Surv. Prof. Paper 503-A, p. Al-A20.

CARROLL, R. L., 1967, Labyrinthodonts from the Joggins Formation: Jour. Paleontology, v. 41, p. $111-142$.

CREA TH, W. G. and SHAW, A. B., 1966, Paleontology of northwestern Vermont - (Pt.) 13 , Isochilina from the Ordovician Highgate Formation: Jour. Paleontology, v. 40, p. 1331-1334.

ERDTMANN, B-D., 1966, Cymatograptus louzonensis, a new graptolite species from the Levis Formation, Quebec (with French abs.): Naturaliste Canadien, v. 93, pp. 247-251.

FRITZ, M. A. , 1966, Diplotrypa schucherti, a new bryozoan species from the Long Point Formation (Ordovician), western Newfoundland: Jour. Paleontology, v. 40, p. 1335-1337.

HAZEL, J. E., 1967, Repandocosta, a new Cretaceous and Tertiary ostracode genus: Jour. Paleontology, v. 4l, p. 103-110.

, Classification and distribution of the Recent Hemicytheridae and

Trachyleberididae (Ostracoda) off northeastern North America: U. S. Geol. Surv., Prof. Paper 564, 49 p.

HOOPER, K., 1966, A note on an anomalous miliolid: Micropaleontology, v. 12, p. 371.

MORRIS, R. W. and KAY, M. , 1966, Ordovician graptolites from the Middle Table Head Formation at Black Cove, near Port au Port, Newfoundland: Jour. Paleontology, v. 40, p. $1223-1229$. 
RIVA, J., 1966, New assemblages of Middle Ordovician graptolites from the Appalachian region, Quebec (with French abs.): Naturaliste Canadien, v. 93, p. 153-156.

SCHOPF, J. M.; MENCHER, E. ; BOUCOT, A. J. ; and ANDREWS, H. N., 1966, Erect plants in the early Silurian of Maine: in Geological Survey research 1966; U. S. Geol. Surv., Prof. Paper 550-D, p. D69-D75.

SHAW, A. B., 1966, Paleontology of northwestern Vermont - (Pt.) 12, Fossils from the Ordovician Highgate Formation: Jour: Paleontology, v. 40, p. 1312-1330.

STEVENSON, J.S. and STEVENSON, L. S., 1966, Fluorine content of microsaur teeth from the Carboniferous rocks of Joggins, Nova Scotia: Science, v. 154, no. 3756, p. 1548-1550.

WILLIAMS, R. B., 1966, Recent marine podocopid Ostracoda of Narragansett Bay, Rhode Island: Kansas Univ. Paleont. Contr., Paper 11, 36 p.

Absolute Age

BOTTINO, M. L. and FULLAGER, P. D., 1966, Whole-rock rubidium-strontium age of the Silurian-Deveonian boundary in northeastern North America: Geol. Soc. Amer., Bull., v. 77, p. $1167-1175$.

McCORTNEY, W. D. ; POOLE, W. H. ; WANLESS, R. K. ; WILliAMS, H. ; and LOVERIDGE, W. D., 1966, Rb/Sr Age and geological setting of the Holy rood granite, southeast Newfoundland: Cdn. Jour. Earth Sci., v. 3, p. 947-957.

Marine Geology, Geophysics and Geochemistry

BALLARD, J.A., 1966, Structure of the lower continental rise hills of the western North Atlantic: Geophysics, v. 31, p. 506-523.

EMERY, K. O., 1966, Atlantic continental shelf and slope of the United States - Geologic background: U. S. Geol. Surv., Prof. Paper 529-A, p. Al-A23.

GARRISON, L. E. and McMASTER, R. L., 1966, Sediments and geomorphology of the continental shelf off southern New England: Marine Geology, v, 4, p. 273-289.

HEEZEN, B. C. and SHERIDAN, R. E., 1966, Lower Cretaceous rocks (Neocomian-Albian) dredged from Blake Escarpment: Sciences, v. 154, no. 3757, p. 1644-1647.

HOOD, P., 1966, Flemish Cap, Galicia Bank, and continental drift: Earth and Planetary Sci. Letters, v. 1, p. 205-208.

KRAUSE, D. C. ; CHRAMIEC, M. A. ; WALSH, G. M. ; and WISOTSKY, S., 1966, Seismic profile showing Cenozoic development of the New England continental margin: Jour. Geophys. Res., v. 71, p. 4327-4332.

ICHIYE, T., 1966, Some hydrodynamic problems for a nepheloid zone: Pure and Applied Geophysics, v. 63, p. 179-195.

LILLEY, H. D., 1966, Late Precambrian and Appalachien tectonics in the light of submarine exploration on the Great Bank of Newfoundland and in the Gulf of St. LawrencePreliminary views: Am. Jour. Sci., v. 264, p. 569-574.

MALLOY, R. L. and HARBISON, R. N., 1966, Marine geology of the north-eastern Gulf of Maine: U.S. Coast and Geod. Surv., Tech. Bull, 28, 15 p.

McFARLIN, P. F., 1967, Aragonite vein fillings in marine manganese nodules: Jour. Sed. Pet., v. 37 , p. $68-72$.

MCMASTER, R. L. and GARRISON, L. E. , 1966, Mineralogy and origin of southern New England shelf sediments: Jour. Sed. Pet., v. 36, p. 1131-1142.

MELSON, W. G. and VanANDEL, Tj. H., 1966, Metamorphism in the Mid-Atlantic Ridge, $22^{\circ} \mathrm{N}$ latitude: Marine Geology, v. 4, p. 165-186.

MILLIMAN, J. D. , 1966, Submarine lithification of carbonate sediments: Science, v. 153 , no. 3739, p. 994-997.

MUIR, I. D. ; TILLEY, C. E.; and SCOON, J. H., 1966, Basalts from the northern part of the Mid-Atlantic Ridge - (Pt. ) 2, The Atlantis collections near $30^{\circ} \mathrm{N}$ : Jour. Petrology, v. 7, p. 193-201.

SAITO, I.; BURCKLE, L. H. ; and EWING, M. , 1966, Lithology and paleontology of the reflective layer horizon A: Science, v. 154, no. 3753, p. 1173-1176.

STAN LEY, E. A., 1966, The application of palynology to oceanology with reference to the northwestern Atlantic: Deep-sea Research, v. 13, p. 921-939.

, The problem of reworked pollen and spores in marine sediments:

Marine Geology, v. 4, p. 397-408.

TUREKIAN, K. K, and IMBRIE, J., 1966, The distribution of trace elements in deep-sea sediments 
of the Atlantic Ocean: Earth and Planetary Sci. Letters, v. 1, p. 161-168.

UCHUPI, E. and EMERY, K. O., 1967, Structure of continental margin off Atlantic Coast of United States: Amer. Assoc. Petrol. Geol., Bull., v. 51, p. 223-234.

\section{Sedimentology and Sedimentary Petrology}

BOND, G. C. and MEADE, R. H. , 1966, Size distribution of mineral grains suspended in Chesapeake Bay and nearby coastal waters: Chesapeake Sci., v. 7, p. 208-212.

DIETZ, R. S, and HOLDEN, J. C., 1966, Miogeoclines (miogeosynclines) in time and space: Jour. Geol., v. 74, p. 566-583.

HAND, B. H. , 1966, Amherst's low-cost flume: Geotimes, v. 11, p. 17-18.

KUENEN, Ph. H., 1966, Experimental turbidite lamination in a circular flume: Jour. Geol. v. 74, p. $523-545$.

TRETTIN, H. P. and HILLS, L. V., 1966, Lower Triassic tar sands of northwestern Melville Island, Arctic Archipelago: Geol. Surv. Can., Paper 66-34, 122 p.

YASSO, W. E., 1966, Formulation and use of fluorescent tracer coatings in sediment transport studies: Sedimentology, v. 6, p. 287-301.

\section{Groundwater Geology}

BRANDON, L. V., 1966, Groundwater probability, Truro (west half), Nova Scotia: Geol. Surv. Can., Map 1160A.

SAMMEL, E. Z.; BAKER, J.A.; and BRACKLEY, R. A., 1966, Water resources of the Ipswich River basin, Massachusetts: U.S. Geol. Surv., Water-Supply Paper 1826, 83 p.

THOMAS, C. E., Jr.; RANDALL, A. D.; and THOMAS, M. P., 1966, Hydrogeologic data in the Quinebourg River basin, Connecticut: Connecticut Water Res., Bull. 9, 84 p.

\section{Miscellaneous}

GRISCOM, A., 1966, Early ascents and geologic exploration of Katahdin in the nineteenth century: in Guidebook for field trips in the Mount Katahdin region, Maine; New England Intercollegiate Geol. Conf., 58th Ann. Mtg. 1966, Augusta, Maine (Maine Geol. Surv.), p. $4-7$.

HENDERSON, B. C. (editor), 1966, Directory of geoscience departments, United States and Canada (1966 edition): Amer. Geol. Inst., Washington, D. C., 186 p.

MAHONEY, L. R. , 1966, 1965 Index of publications of the Geological Survey of Canada: Geol. Surv. Can., Paper 66-3, 70 p.

OILWEEK, 1966, Offshore oil potential rivals western Canada: Oilweek, v. 17, no. 27, p. 30$31,34-35,41-42$.

SPROULE, J.C., 1966, Oil and gas prospects of the Canadian Arctic Islands: in Commonwealth Mining and Metall. Cong., 8th, Australia and New Zealand, 1965, Proc. - Petroleum, Pubs., V. 5; Australasian Inst. Mining and Metallurgy, Melbourne, Australia, p. 57-64.

Latest Items

GROSS, G. A., 1967, Iron deposits in the Appalachian and Grenville regions of Canada, Economic Geology Report No. 22: Geology of iron deposits in Canada. Volume II.

CHRISTIE, R. L., 1967, Bache Peninsula, Ellesmere Island, Arctic Archipelago, Memoir 347.

CUMMIN G, L. M. , 1967, Geology of the Passamaquoddy Bay region, Charlotte County, New Brunswick 21B, 21G (parts of), G. S. C. Paper 65-29.

MILNE, J.E.S. and HOWIE, R. D., 1967, Developments in Eastern Canada, 1966. Am. Assoc. Petrol. Geol. Bull v. 51, No. 6, p. 1163-1173.

WAGNER, F.J.E., 1967, Published references to Champlain Sea faunas 1837-1966 and list of fossils, G. S. C. Paper 67-16. 
The Hugh Lilly Memorial Volume is presently in press and contains the following collected papers on the geology of the Atlantic region:

Forward, by E. R. W. Neals and Harold Williams

Hugh Lilly - An Appreciation, by H. R. Peters

Tectonic Evolution of Appalachian Region of Canada, by W. H. Poole

The Atlantic Continental Margin of the United States during the past 70 Million Years, by K. O. Emery

On the Sediments and Stratigraphy of the Scotian Shelf, by L. H. King

Silurian Rocks of Newfoundland, by $\mathrm{H}$. Williams

Relationship of the Fleur de Lys Group to Younger Groups of the Burlington Peninsula, Newfoundland, by E. R. W. Neale and M. J. Kennedy

Mineral Deposits of the Halls Bay Area, Newfoundland, by H. R. Peters

Basic Volcanic Rocks of the Whalesback Area, Newfoundland, by V.S. Papezik and J. M. Flemin! Structural Studies in the Baie d'Espoir Group, Newfoundland, by F. D. Anderson

Some Notes on Stratigraphy and Structural Style in Central West Newfoundland, by H. D. Lilly

Some Aspects of Carboniferous Stratigraphy and Depositional History in the Atlantic Provinces, by D. G. Kelley

The Significance of Algal Stromatolites to Paleoenvironmental and Chronostratigraphic Interpretation of the Windsorian Stage (Mississippian), Maritime Provinces, by P. E. Schenk

Lithostratigraphic Units in the Upper Part of the Windsor Group, Minas Sub-basin, Nova Scotia, by R. G. Moore

Age and Stratigraphy of the Pictou Group in the Maritime Provinces as Revealed by Fossil Spores, by M.S. Barss and P. A. Hacquebard

Possible Basement Graben Beneath Miramichi Bay, New Brunswick, by R. D. Howie and L. M. Cumming

This Volume will appear as G. A. C. Special Paper No. 4, "Collected Papers on Geology of the Atlantic Region", Hugh Lilly Memorial Volume, edited by E. R. W. Neale and H. Williams. The Paper is scheduled for distribution in November; orders may be placed in advance through the GAC Secretary- Treasurer, Dr. C. R. Barnes, Department of Earth Sciences, University of Waterloo, Waterloo, Ontario, price: $\$ 5.00 \mathrm{GAC}$ members, $\$ 10.00$ non-members and institutions.

General Interest

A NATICNAL SYSTEM FOR STORAGE AND RETRIEVAL OF GEOLOGICAL DATA IN CANADA, Report by the Ad Hoc Committee on Storage and Retrieval of Geological Data in Canada, 1967, 175 p. Figures. Distributed by the Geological Survey of Canada on behalf of the National Advisory Committee on Research in the Geological Sciences.

CANADIAN UPPER MANTLE REPORT, 1967. Published by the Geological Survey of Canada as G. S. C. Paper 67-41.

MAP 1-1967, locating and describing the field parties in more detail, is available from the Geological Survey of Canada, Ottawa.

ANNUAL REPORT, CALENDAR YEAR 1965, Department of Energy, Mines and Resources (formerly Mines and Technical Surveys), Ottawa, Canada. 